\title{
Prevalence of Anemia \& Hypertension their Impact in Elderly People
}

\author{
Maranaj Marku' ${ }^{1}$ Kiri Zallari ${ }^{2}$ \\ ${ }^{1}$ Health Center "Hajmel”, Shkodër Albania \\ ${ }^{2}$ University of Medicine, Tirana, Albania \\ Corresponding E-mail: maranaj.marku[at]gmail.com
}

\begin{abstract}
The aim of our study was to estimate the prevalence of anemia and hypertension among elder persons. We have analyzed medical record reviews of 500 elderly persons (293 men and 207 women) presented in primary care physicians from January 2012December 2014 in Shkoder district. Records data collected from a standardized questionnaire were calculated by SPSS version 19. In our study the prevalence of two diseases anemia and hypertension in elderly person resulted 18.6\% and 46.2\% respectively. The average age was 71.89, with minimum age 65 and maximum 95 years old, Std deviation 11.5. The prevalence of anemia was higher to women compared to men $10.2 \%$ and $8.4 \%$ respectively but in other hand prevalence of hypertension was higher to men compared to women $25 \% \%$ and $21.2 \%$ respectively. The presence of anemia was independently associated with an increased risk of hypertension $95 \%$ CI $p$ value >0.05. Conclusion: The prevalence of anemia and high blood pressure among elderly of Shkodër district is high with a major problem with impacts on social and economic development of our life. We think this is result living in difficult financial conditions and constant stress due to the difficulty at life. More life style factors are significantly associated with anemia and hypertension. So there is an urgent need for calls attention to the elderly.
\end{abstract}

Keywords: Anemia, hypertension, elderly, Shkodër

\section{Introduction}

Anemia and Hypertension represents a global health problem that negatively impacts quality of life in elderly population (defined as people aged $>65$ years). Those two diseases increasing as the population ages and has a significant effect on the quality of life. Anemia is a condition in which the number of red blood cells (and consequently their oxygencarrying capacity) is insufficient to meet the body's physiologic needs. Specific physiologic needs vary with a person's age, gender, residence, smoking behavior, and different stages of pregnancy. Causes of anemia in the elderly are divided into three broad groups: nutritional deficiency, anemia of chronic disease and unexplained anemia [1]. Nutritional deficiencies represent a treatable subgroup and include lack of iron, vitamin B12 or folate [2, 3]. Anemia has been associated with a higher incidence of cardiovascular disease and decreased physical performance and quality of life [4-7]. This disease increase risk of mortality, in particular, mortality related to cardiovascular [4]. Worldwide, raised blood pressure is estimated to cause 7.5 million deaths, about $12.8 \%$ of the total of all deaths. Hypertension is one of the four classical risk factors for coronary heart disease and ischemic as well as haemorrhagic stroke $[8,9]$. The prevalence of hypertension is increasing rapidly in developing countries more in urban areas due to changing life style and increasing longevity of hypertension [10,11]. More studies have shown that hypertension was more associated with family history, age, obesity, diabetes, dietary habits, smoking, and physical inactivity [12-16].

\section{Materials and Methods}

The study population consisted of a sample of 500 elderly more than 65 years old who were presented on primary care physicians during the period January 2012-December 2014.
Data were collected after taking informed consent, of each elderly person. They were interviewed by using a standardized questionnaire, which contains sociodemographic characteristics (age, education, occupation, marital status, etc), and risk factors associated with anemia and hypertension among urban population of Shkoder district. Data were analyzed using SPSS version 19. The mean, frequencies, and rates of the given data for each variable were calculated. Proportions and chi square test were used too. A value of less than 0.05 was considered statistically significant, and adjusted odds ratio with 95\% CI was calculated to determine association.

\section{Results}

Out of 500 elderly patients (293 men and 207 women) presented to primary care physicians during three years (2012-2014) with problem of anemia and hypertension. The prevalence of anemia and hypertension resulted to be $18.6 \%$ (93 cases) and 46.2\% (231 cases) respectively (in both sex men and women).

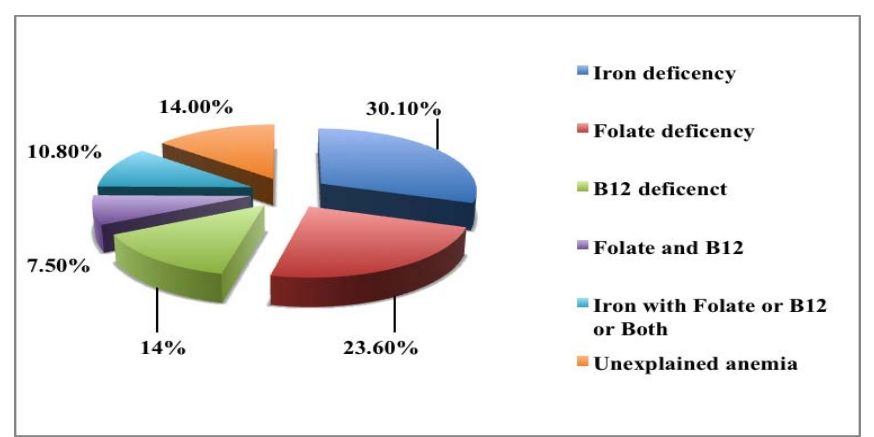

Figure 1: Distribution of types of anemia in population

The average age was 71.89, with minimum age 65 and maximum 95 years old, Std deviation 11.5. The prevalence of 


\section{International Journal of Science and Research (IJSR) \\ ISSN (Online): 2319-7064}

Index Copernicus Value (2013): 6.14 | Impact Factor (2015): 6.391

anemia was higher to women compared to men $10.2 \%$ and $8.4 \%$ respectively but in other hand prevalence of hypertension was higher to men compared to women $25 \% \%$ and $21.2 \%$ respectively. Men were 0.83 times higher in risk with hypertension compared to women with no significant association between them $p=0.2$, for $95 \%$ CI: [0.60 to 1.14 ] and women were 1.16 times in risk with anemia compared to men with no significant association between them $p=0.5$, for 95\% CI: [0.74 to 1.81] (figure 2). The presence of anemia was independently associated with an increased risk of hypertension $95 \%$ CI $p$ value $>0.05$.

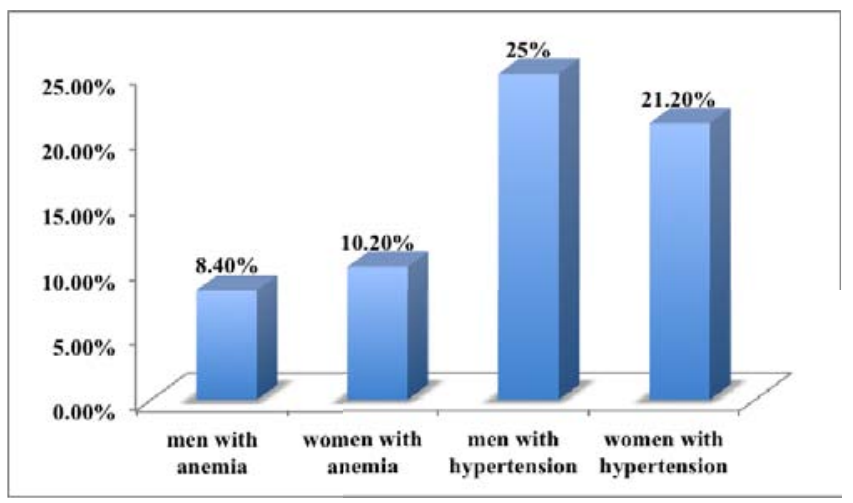

Figure 2: Distribution of patients with anemia and hypertension divided by sex

In figure below we have presented number of patients with hypertension for each age groups. This prevalence is increased with age and peaking at 65-70 years in females and $>71$ years in males. For each age group we have found a significant association between hypertension and anemia. For age group 65-75 years old $p$ value resulted $<0.0001$ for CI $95 \%$ [2.53 to 6.57], for age group 76-85 years old $p$ value resulted $<0.0001$ for CI 95\% [2.34 to 5.34] and for age group $>86$ years old $p$ value resulted $=0.0001$ for CI $95 \%$ [2.2 to 10.5].

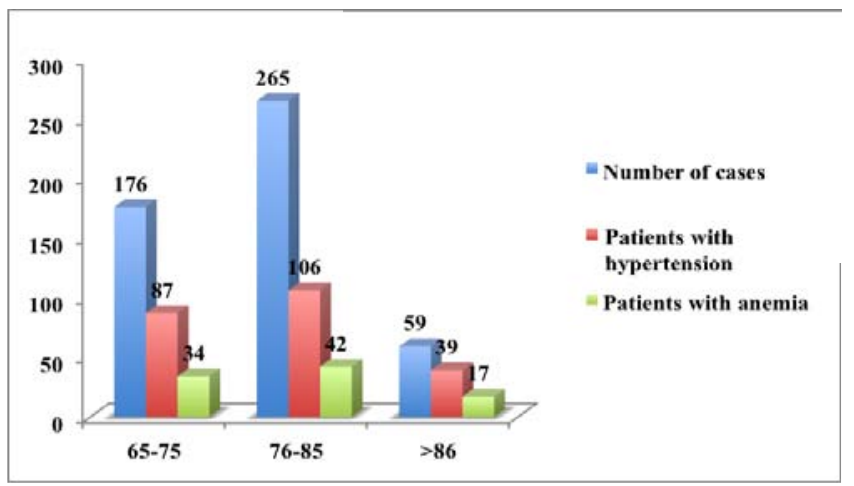

Figure 3: Distribution of patients with anemia and hypertension divided by age groups

In table 1 we have presented socio-demographic characteristics associated with anemia and hypertension such as marital status, education level completed and employment are some of those data.

In table 2 and 3 we have presented data in relation to lifestyle and other important factor risk for hypertension and anemia.

\section{Discussion}

Our study was carried out to evaluate anemia and hypertension among elderly population in relation to factor risk like; family history, age, marital status, obesity, smoking, dietary habits and physical inactivity on Shkodër district of Albania. The present data was collected randomly from the patients presented to the primary care physicians and were accepted to be part of our study. Diagnostic criteria for anemia and hypertension were based on WHO and JNC VII guidelines. For anemia; each hemoglobin level of $<10 \mathrm{~g} / \mathrm{dL}$ were evaluate as an anemia case and for hypertension each SBP $\geq 140 \mathrm{mmHg}$ and/or DBP $\geq 90 \mathrm{mmHg}$ were evaluate as an hypertension case $[17,18]$.

The prevalence of anemia in this study resulted $18.6 \%$ in all age groups. To women this prevalence was higher $10.2 \%$ compared to men $8.4 \%$, but in other hand prevalence of hypertension was higher to men compared to women $25 \% \%$ and $21.2 \%$ respectively with no significance association between them. The presence of anemia was independently associated with an increased risk of hypertension 95\% CI $p$ value $>0.05$.

Iron deficiency is generally assumed to be the major cause of anemia globally $[19,20]$ and affecting a large number 30$40 \%$ of children and women in industrialized [21, 22]. Other factors may cause or be associated with anemia include nutritional deficiencies involving other micronutrients (folate, and vitamin B12), infectious and parasitic diseases (e.g., diarrhea, protozoa, geohelminthosis), glucose-6-phosphate dehydrogenase (G6PD) deficiency, and genetically derived hemoglobinopathies [23-25]. In our study Iron deficiency was higher compared to other types of anemia in $30.1 \%$ of all cases. A high prevalence was seen also for folate and B12 deficiency in $23.6 \%$ and $14 \%$ respectively. Unexplained anemia was seen for $14 \%$ of all cases.

All patients were divided into three age groups from 65 until to 95 years. Anemia and hypertension in our study was increases with age in both sexes. For each group we have found a significant association between anemia and hypertension with $p$ value $<0.0001$.

For the collected data in relation to lifestyle and other important factor risk for anemia and hypertension (table 2 and 3) can be mention that a significant associate were been seen for more of this factors. A significant associate has seen for obesity, physical activity and family history. Obesity persons were 0.39 times higher in risk in their life with a strongly significant association for $\mathrm{p}$ value $=0.002$, persons with family history were 0.34 times higher in risk with $\mathrm{p}$ value $<0.0001$. Persons that have a regular physical activity have a beneficial effect on hypertension compared to them without activity and activity was rarely performed. A strongly significant associate has been seen for persons with moderate activity with $95 \%$ CI [ 0.10 to 0.45 p value $<0.0001$ (table 1 ). About the factor risk for occurrence of anemia we have not found a significance associate between cardiovascular diseases, Diabetes, and intervention during last year's and to other factor risk we have not found a strong significant association explain to table 3. 


\section{International Journal of Science and Research (IJSR) \\ ISSN (Online): 2319-7064}

Index Copernicus Value (2013): 6.14 | Impact Factor (2015): 6.391

This epidemiological transition could partially be explained by the rapid urbanization with changes in lifestyles, especially dietary habits and physical activity patterns and the group that appears to be most at risk for anemia and hypertension are those individuals of low to medium socio-economic status in urban areas [26].

\section{Conclusion}

The prevalence of anemia and high blood pressure among elderly of Shkodër district is high. It is a major problem with impacts on social and economic development of our life. We think this is result living in difficult financial conditions and constant stress due to the difficulty at life. More life style factors are significantly associated with anemia and hypertension. So there is an urgent need for calls attention to the elderly.

\section{Reference}

[1] Reinhard Stauder, Swee Lay Thein. Anemia In The Elderly: Clinical Implications And New Therapeutic Concepts. Haematologica July 2014 99: 1127-1130; Doi:10.3324/haematol.2014.109967.

[2] Assessing the iron status of populations: report of a joint World Health Organization/ Centers for Disease Control and Prevention technical consultation on the assessment of iron status at the population level, 2nd ed., Geneva, World Health Organization, 2007. Available at http://www.who.int/nutrition/publications/micronutrients/ anaemia_iron_deficiency/9789241596107.pdf

[3] World Health Organization. 2011. Haemoglobin concentrations for the diagnosis of anaemia. www.who.int/vmnis/indicators/haemoglobin.pdf.

[4] Culleton BF, Manns BJ, Zhang J, Tonelli M, Klarenbach $\mathrm{S}$, Hemmelgarn BR. Impact of anemia on hospitalization and mortality in older adults. Blood. 2006;107(10):38416.Abstract/FREE Full Text

[5] Beghe C, Wilson A, Ershler WB. Prevalence and outcomes of anemia in geriatrics: a systematic review of the literature. Am J Med. 2004; 116(Suppl 7A):3S10S.Medline.

[6] den Elzen WP, Willems JM, Westendorp RG, de Craen AJ, Assendelft WJ, Gussekloo J. Effect of anemia and comorbidity on functional status and mortality in old age: results from the Leiden 85-plus Study. Can Med Assoc J. 2009; 181(3-4):151-7.Abstract/FREE Full Text.

[7] Penninx BW, Pahor M, Cesari M, Corsi AM, Woodman RC, Bandinelli S, et al. Anemia is associated with disability and decreased physical performance and muscle strength in the elderly. $J$ Am Geriatr Soc. 2004;52(5):719-24.CrossRefMedlineWeb of Science.

[8] World Health Organisation. 2016. http://www.who.int/gho/ncd/risk_factors/blood_pressure _prevalence_text.

[9] Kannel WB, Sorlie P, Gordon T. Labile hypertension: a faulty concept? The Framingham study. Circulation. 1980; 61:1183-7.

[10] Omondi DO, Othuon L, Mbagaya GM. (2007). Physical activity patterns, dietary intake and health status among university of Nairobi lecturers in Kenya. S Afr J Res Sport Phys Educ Recreation, 29(2): 87-98.

[11] Madhumitha M., Naraintran S., Manohar C., Revathi S., Mallikarjun K. Biradar, R.S. Patil. 2014 hypertension prevalence and risk factors among urban population in north karnataka. International journal of current research and review; 6(7): 39-45.

[12] Hamet P, Pausova Z, Adarichev V, Adaricheva K, Tremblay J. Hypertens: Genes and Environment. J Hypertens. 1998;16:397-418. PMID: 9797185

[13] Hu G, Tian H. 2001. A comparison of dietary and nondietary factors of hypertension and normal blood pressure in a Chinese population. J Hum Hypertens; 15: 487-93. PMID: 11464259.

[14] World Heart Organization. 1990. Study Group. Diet, Nutrition, and the Prevention of Chronic Diseases. WHO Technical Report Series No. 797. Geneva: WHO.

[15] Borrell C, Rue M, Pasarin MI, Rohlfs I, Ferrando J, Fernandez E. 2000. Trends in social class inequalities in health status, healthrelated behaviors, and health services utilization in a Southern European urban area (19831994). Prev Med 31:691-701. doi: 10.1006/pmed.0751.

[16] Jousilahti P, Tuomilehto J, Vartiainen E, Valle T, Nissinen A. 1995. Body mass index, blood pressure, diabetes and the risk of anti-hypertensive drug treatment: 12-year follow-up of middle-aged people in eastern Finland. J Hum Hypertens. 9:847-54. PMID: 8576902.

[17]World Health Organization, 2011, Haemoglobin concentrations for the diagnosis of anaemia. www.who.int/vmnis/indicators/haemoglobin.pdf

[18] Mancia G, De Backer G, Dominiczak A, et al. (2007) 2007 Guidelines for the management of arterial hypertension: The Task Force for the Management of Arterial Hypertension of the European Society of Hypertension (ESH) and of the European Society of Cardiology (ESC). Eur Heart J 28: 1462-1536.

[19] Bernoist B, McLean E, Egli I, Cogswell M: Worldwide Prevalence of Anaemia 1993-2005: WHO Global Database on Anaemia. Geneva: World Health Organization; 2008.

[20] World Health Organization (WHO). 2001: Iron Deficiency Anaemia Assessment, Prevention and Control. A Guide for Programme Managers. Geneva: World Health Organization.

[21] Victora CG, Huttly SR, Fuchs SC, Olinto MTA: The role of conceptual frameworks in epidemiological analysis: a hierarchical approach. Int J Epidemiol 1997, 26:224227. View Article

[22] Sinha N, Deshmukh PR, Garg BS: Epidemiological correlates of nutritional anemia among children (6-35 months) in rural Wardha, Central India. Indian J Med Sci 2008, 62:45-54.View Article

[23] Milman N: Anemia - still a major health problem in many parts of the world! Ann Hematol 2011, 90:369377. View Article

[24] Howard CT, de Pee S, Sari M, Bloem MW, Semba RD: Association of diarrhea with anemia among children under age five living in rural areas of Indonesia. $J$ Trop Pediatr 2007, 53:238-244

[25] García-Casal MN, Leets I, Bracho C, Hidalgo M, Bastidas G, Gomez A, Peña A, Pérez H: Prevalence of anemia and deficiencies of iron, folic acid and vitamin B- 


\section{International Journal of Science and Research (IJSR) \\ ISSN (Online): 2319-7064 \\ Index Copernicus Value (2013): 6.14 $\mid$ Impact Factor (2015): 6.391}

12 in an indigenous community from the Venezuelan Amazon with a high incidence of malaria. Arch Latinoam Nutr 2008, 58:12-18.

[26] Omondi DO, Othuon L, Mbagaya GM. (2007). Physical activity patterns, dietary intake and health status among university of Nairobi lecturers in Kenya. S Afr J Res Sport Phys Educ Recreation, 29(2): 87-98.

Table 1: Socio-demographic characteristics associated with anemia and hypertension

\begin{tabular}{|c|c|c|c|}
\hline $\begin{array}{c}\text { Socio-demographic } \\
\text { Characteristics }\end{array}$ & $\begin{array}{c}\text { Number of patients } \\
(500)\end{array}$ & $\begin{array}{c}\text { Patients with anemia } \\
\text { (93) }\end{array}$ & $\begin{array}{c}\text { Patients with hypertension } \\
\text { (231) }\end{array}$ \\
\hline \multicolumn{4}{|l|}{ Marital status } \\
\hline Married & 302 & 57 & 137 \\
\hline Widow & 198 & 36 & 94 \\
\hline \multicolumn{4}{|c|}{ Education level completed } \\
\hline University & 102 & 23 & 66 \\
\hline High school & 329 & 51 & 108 \\
\hline$\leq 8$ years & 69 & 19 & 57 \\
\hline \multicolumn{4}{|l|}{ Employment } \\
\hline Employment & 51 & 7 & 32 \\
\hline Retired & 449 & 86 & 468 \\
\hline \multicolumn{4}{|l|}{ Family monthly income } \\
\hline High level & 38 & 9 & 21 \\
\hline Middle level & 129 & 34 & 87 \\
\hline Low level & 333 & 50 & 123 \\
\hline
\end{tabular}

Table 2 Regression logistic of risk factors associated with hypertension

\begin{tabular}{|c|c|c|c|c|}
\hline Characteristics of samples & $\begin{array}{l}\text { Patients } \\
(500)\end{array}$ & $\begin{array}{c}\text { With hypertension } \\
\text { (231) }\end{array}$ & $\begin{array}{c}\text { Odds ratio } \\
(95 \% \text { CI) }\end{array}$ & $p$ value \\
\hline \multicolumn{5}{|l|}{ Smoker } \\
\hline Never smoked & 257 & 109 & 1 (reference) & \\
\hline Current smoker & 243 & 122 & $\begin{array}{c}0.73 \\
0.51 \text { to } 1.03\end{array}$ & $p=0.08$ \\
\hline \multicolumn{5}{|c|}{$\mathrm{BMI} / \mathrm{Kg} \mathrm{cm}^{2}$} \\
\hline$<25$ & 72 & 29 & 1 (reference) & \\
\hline $25-<30$ & 284 & 108 & $\begin{array}{c}1.09 \\
0.64 \text { to } 1.86 \\
\end{array}$ & $p=0.72$ \\
\hline$>30$ & 144 & 94 & $\begin{array}{c}0.39 \\
0.21 \text { to } 0.71 \\
\end{array}$ & $p=0.0023$ \\
\hline \multicolumn{5}{|c|}{ Alcohol intake } \\
\hline No users & 231 & 96 & 1 (reference) & \\
\hline Users & 269 & 135 & $\begin{array}{c}0.7 \\
0.49 \text { to } 1.00 \\
\end{array}$ & $p=0.054$ \\
\hline \multicolumn{5}{|c|}{ Family history. } \\
\hline No & 154 & 105 & 1 (reference) & \\
\hline Yes & 346 & 126 & $\begin{array}{c}0.34 \\
0.19 \text { to } 0.60 \\
\end{array}$ & $p=0.0003$ \\
\hline \multicolumn{5}{|c|}{ Physical activity } \\
\hline Yes & 49 & 16 & 1 (reference) & \\
\hline Some time & 121 & 83 & $\begin{array}{c}0.23 \\
0.10 \text { to } 0.45\end{array}$ & $P<0.0001$ \\
\hline None & 330 & 132 & $\begin{array}{c}0.72 \\
0.38 \text { to } 1.37\end{array}$ & $p=0.3$ \\
\hline
\end{tabular}


International Journal of Science and Research (IJSR)

ISSN (Online): 2319-7064

Index Copernicus Value (2013): 6.14 | Impact Factor (2015): 6.391

Table 3 Regression logistic of risk factors associated with Anemia

\begin{tabular}{|c|c|c|c|c|}
\hline Characteristics & $\begin{array}{l}\text { Number of patients } \\
(500)\end{array}$ & $\begin{array}{l}\text { Patients with anemia } \\
\text { (93) }\end{array}$ & $\begin{array}{c}\text { Odds ratio } \\
(95 \% \mathrm{CI})\end{array}$ & $p$ value \\
\hline \multicolumn{5}{|c|}{ Eating animal products } \\
\hline No & 96 & 56 & 1 (reference) & \\
\hline Yes & 404 & 37 & $\begin{array}{c}13.88 \\
8.18 \text { to } 23.54 \\
\end{array}$ & $p<.0 .0001$ \\
\hline \multicolumn{5}{|c|}{ Eating green leafy vegetables } \\
\hline No & 67 & 39 & 1 (reference) & \\
\hline Yes & 433 & 54 & $\begin{array}{c}9.42 \\
5.38 \text { to } 16.51 \\
\end{array}$ & $p<.0 .0001$ \\
\hline \multicolumn{5}{|c|}{ Presence of parasites } \\
\hline No & 476 & 84 & 1 (reference) & \\
\hline Yes & 24 & 9 & $\begin{array}{c}0.35 \\
0.15 \text { to } 0.84 \\
\end{array}$ & $p=0.018$ \\
\hline \multicolumn{5}{|c|}{ Presence of hypertension } \\
\hline No & 269 & 24 & 1 (reference) & \\
\hline Yes & 231 & 69 & $\begin{array}{c}0.23 \\
0.13 \text { to } 0.38\end{array}$ & $\mathrm{p}<0.0001$ \\
\hline \multicolumn{5}{|c|}{ Presence of cardiovascular diseases } \\
\hline No & 346 & 58 & 1 (re ference) & \\
\hline Yes & 154 & 35 & $\begin{array}{c}0.68 \\
0.42 \text { to } 1.09\end{array}$ & $p=0.11$ \\
\hline \multicolumn{5}{|c|}{ Presence of diabetes } \\
\hline No & 321 & 53 & 1 (reference) & \\
\hline Yes & 179 & 40 & $\begin{array}{c}0.68 \\
0.43 \text { to } 1.08\end{array}$ & $p=0.10$ \\
\hline \multicolumn{5}{|c|}{ Presence of other diseases } \\
\hline Yes & 92 & 29 & 1 (reference) & \\
\hline No & 408 & 64 & $\begin{array}{c}2.47 \\
1.47 \text { to } 4.13\end{array}$ & $p=0.0006$ \\
\hline \multicolumn{5}{|c|}{$\begin{array}{l}\text { Presence of intervention during last } \\
\text { years }\end{array}$} \\
\hline No & 448 & 85 & 1 (reference) & \\
\hline Yes & 52 & 8 & $\begin{array}{c}1.28 \\
0.58 \text { to } 2.83\end{array}$ & $p=0.5$ \\
\hline \multicolumn{5}{|c|}{$\mathrm{BMI} / \mathrm{Kg} \mathrm{\textrm {cm } ^ { 2 }}$} \\
\hline$<25$ & 72 & 17 & 1 (reference) & \\
\hline $25-<30$ & 284 & 34 & $\begin{array}{c}2.27 \\
0.18 \text { to } 14.35\end{array}$ & $p=0.01$ \\
\hline$>30$ & 144 & 42 & $\begin{array}{c}0.75 \\
0.39 \text { to } 1.44\end{array}$ & $p=0.38$ \\
\hline \multicolumn{5}{|c|}{ Family history } \\
\hline No & 452 & 48 & 1 (reference) & \\
\hline Yes & 48 & 45 & $\begin{array}{c}0.007 \\
0.0024 \text { to } 0.0026\end{array}$ & $p<0.0001$ \\
\hline
\end{tabular}

Volume 5 Issue 4, April 2016 